\title{
DÜBLIN
}

Technological University Dublin ARROW@TU Dublin

2009-01-01

\section{Developing Consumer Subjectivity in Ireland: 1900-80}

\author{
Paddy Dolan \\ Technological University Dublin, paddy.dolan@tudublin.ie
}

Follow this and additional works at: https://arrow.tudublin.ie/clsart

Part of the Social and Behavioral Sciences Commons

\section{Recommended Citation}

Dolan, P. (2009) Developing Consumer Subjectivity in Ireland: 1900-80. Journal of Consumer Culture, vol.9, no.1, pp. 117-41. doi:10.1177/1469540508099702

This Article is brought to you for free and open access by the Centre for Consumption and Leisure Studies at ARROW@TU Dublin. It has been accepted for inclusion in Articles by an authorized administrator of ARROW@TU Dublin. For more information, please contact arrow.admin@tudublin.ie, aisling.coyne@tudublin.ie, gerard.connolly@tudublin.ie.

Funder: Irish Research Council for the Humanities and Social Sciences 
Author: $\quad$ Dolan, Paddy

Title: $\quad$ Developing Consumer Subjectivity in Ireland: 1900-80

Originally published in Journal of Consumer Culture, Vol 9(1): 117-141. Copyright Sage.

The publisher's version is available at: http://joc.sagepub.com/cgi/content/abstract/9/1/117

Please cite the publisher's version:

Dolan, Paddy (2009) 'Developing Consumer Subjectivity in Ireland: 1900-80', Journal of Consumer Culture 9(1): 117-41.

ISSN 1469-5405 [DOI: 10.1177/1469540508099702]

This document is the author's final manuscript version of the journal article, incorporating any revisions agreed during peer review. Some differences between this version and the publisher's version remain. You are advised to consult the publisher's version if you wish to cite from it.

Copyright (C) and Moral Rights for the papers on this site are retained by the individual authors and/or other copyright owners. 


\title{
ARTICLE
}

\section{Developing Consumer Subjectivity in Ireland: 1900-80}

\author{
PADDY DOLAN
}

Dublin Institute of Technology, Ireland

\begin{abstract}
The development of consumer subjectivity cannot be solely understood in terms of the intentions, strategies and discursive practices emanating from diverse power centres. Following Elias, and using Ireland as an empirical case, the consumer is presented as undergoing a shift along a continuum of We-I balances towards the latter pole. This occurs within the context of increasing social interdependencies, functional specialization and social integration. Through complex, unplanned social processes over time, the consumer is seen more individualistically. I conclude by suggesting that there are opportunities to synthesize figurational and Foucauldian approaches to consumer subjectivity once long-term social change is prioritized.
\end{abstract}

Key words

consumer culture $\bullet$ figurations $\bullet$ habitus $\bullet$ individualization $\bullet$ Norbert Elias

\section{INTRODUCTION}

The question of who the consumer is has received considerable attention in recent years, and is often an implicit assumption in many academic accounts of consumer culture. Slater (1997: 33-62) argues that modern thought tends to characterize the consumer as either hero or dupe, someone in rational control of their interests and how to satisfy them, or someone manipulated by the machinations of the market and its operators. In the former social category the consumer has sovereignty over their own needs and desires, which are private and normatively beyond the control or determination by others. The latter model denotes the consumer as a more passive recipient of information and persuasion regarding the type of life one should lead and the means to conform to it. Clearly, these oppositional models raise questions about subjectivity, or the extent to which one is expected to conform to broader social expectations and ideals in practices of consumption, or alternatively, rely exclusively on one's own dispositions to steer one's actions in the marketplace.

However, following Norbert Elias, this academic choice is a false opposition; each consumer is a person constrained and enabled through the fluid social network that he or she comprises. Under the social conditions of increasing functional specialization, and multiplying as well as lengthening links of interdependencies, people increasingly think, feel and act more like individuals and this habitus is both embodied and enacted in consumption practices and symbolically represented in new concepts of the consumer. People move along the continuum 
between social control and self- direction (though this always remains a tension balance) or the we-I balance (see Elias, 1991a). The extent of this individualization of the consuming subject depends on other social processes over which no particular social group, e.g. advertisers or producers, has complete control. The 'consumer' as a self-directing individual is a symbolic ideal generated in unplanned, but structured, ways through the complex and changing relationships between people over generations. This type of consumer is also partly a social reality in that people are expected to know their needs and wants and the means to their fulfilment. People have come to regard their 'inner' desires and choices (apparently free of social compulsion) as a legitimate basis for consumption practices; they increasingly see themselves as individual subjects of choice. That desires are neither asocial nor presocial does not negate this individual feeling. Certainly opportunities for more collective consumption experiences do not disappear (such as sport spectatorship), and some practices continue to have class rather than subjective connotations, but in Ireland at least, and over the period concerned, the balance has shifted toward the individual as agent or centre of choice.

Following Trentmann (2006a, 2006b), we need to see consumer subjectivity in a more sociohistorical context. The expected capacities, freedoms and duties of 'the consumer' vary over time and space; consequently, we should address the consumer as a social category and process, and develop explanations of how the subject of consumption has changed. This cannot be universalized because each society has undergone distinct, though interrelated, processes of social development. I examine such processes using Ireland as an empirical case. Irish society is an interesting case study for a number of reasons. It does not correspond to the ideal type trajectory of the modernity of 'the West' (though one could certainly argue that no particular country fits this model exactly). Modern consumer culture arose 'as part of the west's assertion of its own difference from the rest of the world as modern, progressive, free, rational' (Slater, 1997: 9). Elias (2000: 5) also connects the concept of civilization with the superior, progressive attitude of the West towards colonized peoples. Ireland occupies a complicated position in relation to western colonialism having been colonized by Britain. Indeed the depiction of the Irish in the late 19th century (and beyond) as backward and irrational is well known (Ashley, 2001; Curtis, 1997). Several social processes associated with modernity, such as industrialization and urbanization, have also occurred late in Irish history, accelerating from the middle of the 20th century onwards. These structures of social change are connected to particular trajectories of the values and morals surrounding consumption, and also to the expected conduct of people in their acquisition and use of goods. Ireland is not peculiar in the sense that it alone is unique in its consumer culture. Trentmann (2006b: 51) shows how Britain, Germany, China and Japan all differ in their dominant conceptions of the identity of the consumer. In the first instance, this means exploring the consumer in a national-specific way.

Seeing consumer subjectivity as contingent has been addressed by governmentality scholars, and those adopting a general Foucauldian perspective. Although there is some potential overlap between Eliasian and Foucauldian perspectives, the latter approach tends towards more direct and intentionalist accounts of the emergence of new types of consuming subjects. This article can be read as a counter-argument to Delhaye's (2006) recent fascinating account 
of the development of the female consumer in the Netherlands, where she explicitly opted for Foucault over Elias.

Before arguing for the relevance of Elias to the study of the consumer, it is perhaps appropriate to address the title of this article. By 'developing', I am referring to a largely unintended process, though, following Elias, I argue that there is a discernable order to this unplanned trajectory. The socially assumed expectations regarding the capacities and disposition of the person who consumes, the subjectivity of the consumer, changes in a particular direction, though unevenly, and this change is not presented as a direct result of the ambitions or strategies of advertisers, industrialists, educators, experts or politicians. Though these functional specialists play their part in the overall story, they are themselves guided by a broader social dynamic, rather than discourse alone, that shapes the needs and emotions of all members of society, though in class- and gender-specific ways. The periodization under examination here has been identified through an analysis and synthesis of relevant data; I identify a significant shift in the connotations of the consumer during this phase. It is likely that earlier changes occurred and that the meanings and rights of the consumer continue to change. As Elias (1983: 232) states, 'nothing is more fruitless, when dealing with long-term social processes, than to attempt to locate an absolute beginning', nor indeed an absolute end. Before highlighting Elias's theories relevant to consumer subjectivity, I first examine Foucauldian approaches in order to locate the benefits of a more figurational (Eliasian) perspective.

\section{DISCURSIVE SUBJECTIVITIES}

Foucauldian approaches to the consumer tend to emphasize the production of this subjectivity through the practical or technical deployment of discourses (see for example, Delhaye, 2006; Hackley, 2002; Jantzen, et al., 2006; Miller and Rose, 1997; Schild, 2007). These studies, amongst others, demonstrate through an analysis of a diversity of texts and techniques (such as magazines, government social policy documents, the research findings of marketing research and advertising agencies, consumer education manuals) how key experts or authorities discursively construct ideal or normative models of how to consume efficiently, rationally or authentically. However, there is a sense here in which subjectivity is defined, a priori, as the result of discursive techniques; consequently, such discourses can no longer be used to explain the emergence of specific subjectivities. There is no space for alternative theories of self-formation as they tend to be ruled out by definition. Certainly marketing practices often seek to 'discover' the motivations of potential consumers, and steer their brand preferences through advertising or other promotional devices. This is an intentional practice in the interests of the producer. But it often fails, or when it works (i.e. sales of the brand increase), the precise reason for success is obscure. In terms of creating the capacity to consume, it is doubtful that this is solely the result of using psychological discourses in marketing practice. The concentration on discourse alone as a disembodied and asocial/pre-social formation gives the impression that words are independent of human beings in general, as opposed to particular individuals (see Elias, 1991b). 
Miller and Rose (1997) show how psychological sciences, based on the concept of the autonomous individual (though in different theoretical forms), have been utilized by leading British companies since the Second World War in order to construct advertisements. The manipulation thesis is explicitly eschewed in favour of a model of the 'productive' features of psychological and marketing techniques - the production of consumer subjectivity. Indeed, Rose's (1990) work has been seminal in the application of Foucault to studies of consumption. This work has stressed the need to focus on a multiplicity of practices and techniques, so that diverse forms of subjectivity can be seen to co-exist in potential contradiction. But Rose assumes that these discursive injunctions to live a certain style of life, and to relate to oneself in particular ways through practices of consumption, can be simply 'read off' the objectives of market researchers (see Binkley, 2006: 351). We are also left to assume the effectiveness of these injunctions, inscriptions and other bureaucratic techniques. In a study of how new consumer-centric discourses affect the provision of public services, Clarke (2007) shows that providers may accept the user as a consumer with personal experiences, but must rely on their professional expertise within the constraints of limited resources. Clarke and Newman (cited in Clarke, 2007: 174) note that service users rarely see themselves as consumers, despite the new discourse of government policies (see also Trentmann, 2007).

Rose (1996a, 1996b) denies any broader social structural changes in the production of types of selfhood. Indeed, subjectivity is seen as the effect of localized techniques of inscription 'governed by a more or less conscious goal' (Rose, 1996b: 132); the concept of unplanned but structured change over time, so central to Elias, is largely dismissed. Delhaye (2006) disagrees with Rose's dismissal of historical sociological approaches to subjectivity, yet accepts his interpretation that Elias's theories are themselves based on a Freudian theory of the self. While Elias was certainly influenced by Freud, he seeks to historicize the structure of the habitus in the context of changing social structures over many generations. The psychoanalytic model of personality is not the central basis of his theoretical-empirical work. To proceed with such an enquiry without any 'theory of the self' (Rose, 1996a: 306) would represent a case of naïve empiricism.

\section{FIGURATIONAL SUBJECTIVITES}

Elias did not use the term 'subjectivity' to connote the agency, capacities or personal dispositions of the individual, preferring the term 'habitus', which was of course subsequently adopted by Bourdieu. However, the term is useful in order to connect to current debates on the nature of the choosing individual in consumption studies. In particular, it enables a close comparison with Foucauldian approaches to the consumer. Elias's (1991a, 2000) theories concern how people came to experience themselves as isolated, closed individuals (homo clausus) within the context of increasing social interdependencies. He uses examples from successive etiquette texts of the Middle Ages to show the advancing thresholds of repugnance and embarrassment in relation to eating practices and other bodily functions. More and more formerly licentious conduct became a source of anxiety and shame. People increasingly had to observe others and observe themselves in the context of persistent mutual judgement and adjustment in social situations. These social processes started first in 
the European aristocratic courts, as members of the provincial nobility came under the close scrutiny of monarchs (pace Delhaye, Elias does address in great detail the multiple and changing social situations involving increasing mutual observation between people comprising tightening networks).

This occurred with the changing social context of the state (monarchy) monopolization of the means of violence and taxation, which were intertwined. These state monopolies encouraged greater functional specialization and the monetization of the economy, which in turn allowed for increasing social interdependencies between people of various social classes. Such growing pressures by a multitude of people on each individual in their midst encouraged a more circumspect and calculating subjectivity. Social constraints demanded a more even and continuous self-restraint. Thus there occurred a shift in the we-I balance toward the latter pole. This balance is a continuum rather than a dichotomy; people socialized within more complex societies, constituted by dense and extensive mutual links, tend towards heightened feelings of individual distinction. Of course this is partly due to changing 'discourses' of the person towards more individualized ideals, but this symbolic and normative development occurs through broader social structural changes. The 'consumer' is one aspect of the person, and so we would expect a change in the meaning and function of this type of subject within the context of increasing functional specialization, social interdependencies and social integration.

I do not seek to establish the definition of the 'authentic' consumer, but to trace the changing meanings, values and emotional connotations of this type of subject over time. As Trentmann (2006a: 9) notes: 'Different traditions and social milieus made for different national and regional stories of the consumer.' Specific ideas of the consumer are sociosymbolically constructed depending on the changing structure of social relationships over time. As these developing structures vary from country to country, we cannot posit an abstract, generalizable 'ideal type' of consuming subject, though similarities across space may occur due to analogous social structural change. Elias's approach is useful for the study of consumer subjectivity for several reasons. First, societies change, and as part of that change, so too do attitudes, rights, duties, emotions and norms of individualism. Consequently, every aspect of social life must be examined as a process in order to explain it. Second, Elias shows that the dualistic agency-structure model dominant in sociology, and often reproduced in consumption studies, is a false dichotomy; individuals are formed through their changing social relationships. Elias uses the term 'figuration' to refer to this unplanned but ordered dynamic network of interdependent people. Figurations can be conceived, inter alia, as families, communities, tribes, trade unions, governments and nation states. They overlap and exist in tension; relations between people comprising a figuration, because of their mutual dependencies, are liable to power ratios and shifts, and tensions are normal rather than dysfunctional. So shifting power relations between interdependent groups and individuals are central to the overall dynamic of change. 


\section{METHODS}

At a relatively high level of social integration (the state and government), power relations are played out in national political arenas such as parliaments. Brewer and Trentmann (2006: 10) argue that 'Politics has been a crucial conduit through which the values, practices and identities of consumption have been shaped', a point supported by others (Cohen, 1998; Cohen, 2001; Cross, 1993; Hilton, 2001). Consequently, this article relies on data derived form parliamentary debates in Ireland, supplemented by diaries, advertisements and memoirs, in order to see the changing moral and emotional connotations of the consumer, particularly in terms of the tension between the social duty to adhere to communal standards of consumption and the proclaimed sovereign right of each individual to follow their own dispositions and predilections. This comparison, of course, echoes Cohen's work, but here I attempt a more figurational approach by connecting such changes to broader, unplanned structural developments.

Elias (1987) advocates a relative detachment in relation to our objects of investigation in order to establish more adequate knowledge, less coloured by our desire for a better world. Ironically, Elias argued that knowledge generated less from our wishes and more from our observations offers greater potential for mastering social processes and thereby directing them to a greater extent. Both Miller (2001) and Brewer and Trentmann (2006: 4) note the prevailing moralistic tone in consumption studies, while the latter espouse the examination of 'the changing moral landscape of consumption'.

Such relative detachment is perhaps more difficult when examining one's own nation, but it is important to convey some brief historical context for the following discussion. The political nature of Ireland continues to be contested, so of course her history is too. This context is based on an interpretation of leading historiographical texts of the period (Kee, 2000; Keogh, 1994; Lee, 1989a, 1989b), and emanates from a broader socio logical study (Dolan, 2005). Ireland had long been a territorial possession of the English crown, but became an integral part of the United Kingdom of Great Britain and Ireland in 1801. With the advent of free trade, the territories of Ireland and Britain tended towards even greater specialization in agriculture and industry respectively. This increasing interdependency between nations within the same state and under the cultural historical context of felt repression and inequality (the emancipation of Catholicism, the majority religion in Ireland, occurred in 1829 while the Protestant Church of Ireland, the main religion of the landed gentry, was not disestablished by the British parliament until 1869).

Ironically, the closer economic relations between Ireland and Britain tilted the power balance between landlords and tenant-farmers in Ireland in favour of the latter. As a result of the significant class, ethnic and religious divide between these two groups, such decreasing power differentials often led to violent encounters. The failure of the Irish Parliamentary Party to secure Home Rule through constitutional means opened the space for rising middle- and lower-middle-class groups to form new political alliances prepared to use violence in order to attain Irish independence. One of these groups, Sinn Féin, espoused a form of economic nationalism to complement separatist hopes, and became the basis for 
the development of the two main political parties in Ireland after the Civil War of 1922-23. Following armed insurrections in 1916 and 1919-21 a measure of political independence was attained through the disputed Treaty of 1921. Those against the Treaty, who were defeated in the Civil War, eventually formed the political party Fianna Fáil in 1926 and went on to dominate Irish government up to the present day. They achieved power in 1932 and, but for two brief periods (1948-51 and 1954-57), remained in government until 1973. While Fianna Fáil espoused economic nationalism in the 1930s and 1940s, these policies were generally not decried by other parties. The main parties were derived from the 'spirit' of nationalism that became stronger in the late 19th and early 20th centuries, and this coloured economic policies and international relations. Ideally, consumption was to be as nationalistic as other social activities; people were expected to buy and use Irish goods. The most relevant aspects of this necessarily brief historical description are elaborated further in the following sections.

The article proceeds with a selection of quotes from parliamentary debates, diaries, historiographic texts and advertisements, before positing a model of figurational change in Ireland over the period concerned. Parliamentary debates offer relevant data sources because of their dialogic and oppositional character; because of the structural competitive relations between political parties, statements come under the scrutiny of others in the parliamentary chamber. Such statements are based on the tacit knowledge, feelings and values of the speaker; they are quickly contested if not seen as 'taken-for-granted' knowledge. This enables the researcher to distinguish between accepted norms and values and those considered 'out of the ordinary'.

I conclude by making connections between these symbolic and social shifts, and highlighting the benefits of this alternative figurational understanding of consumer subjectivity.

\section{CHANGING CONSUMER SUBJECTIVITIES}

The consumer is not always an explicit concept in political discourse, and much of the meaning is implicit and revealed by examining the normativity of aspects of consumption as discussed in parliamentary dialogue, and revealed in various texts. By consumer subjectivity, I mean the degree to which one is expected to follow prescribed norms and morals of consumption, or pursue one's own felt needs and wants in the market. These prescriptive models of the consuming subject are seen along a continuum rather than representing oppositional types. They overlap and exist in tension in the Irish case largely because of class relations and habitus, but the ideal of the sovereign consumer comes to dominate.

The movements in the meaning and function of the consumer are by no means even and linear. However, a shift in the direction from consumption as a collective and socially regulated process towards a more self-determined process can be detected. This supports Wouters's (2004) finding that over the course of the 20th century personal identity superseded the earlier emphasis on group identity, a finding entirely consistent with the thrust of Elias's work. Similarly, Hilton (2001) notes a change in emphasis from the duties to the rights of the consumer in Britain since the Second World War. As an historian, of course, Hilton does not explain this shift in sociological terms. In Ireland during the first half of the 
$20^{\text {th }}$ century, a common social standard of consumption was emphasized. People were depicted with more or less common and constrained needs and desires, and individuals were implicitly expected to want similar objects and experiences. Their wants were located within a social context such that the centre of need or desire was less the individual by virtue of his or her unique disposition, but by virtue of their membership of a particular social group. The sense of one's individuality, uniqueness and power to decide, regarding consumption practices, was also somewhat class-specific in that the professional classes placed greater emphasis on this capacity. The argument is not that people did not act as individuals in the early part of the century and towards the end of that century they had begun to do so. Rather, the individual became more pronounced over that period as the subject of choice. Social constraints towards more self-restraint, self-compulsion and self-expression advanced. Affiliations to social groups, including the nation, by no means disappeared, but it became increasingly up to the individual person to express those affiliations in the form of consumption practices.

At the turn of the 20th century, there were lower thresholds of shame regarding consumption practices. In 1904, one diarist, an architect, hopefully imagined theatre audiences 'conducting themselves with some semblance of good manners and not demanding encores for every item or leaving noisily during the items that do not please them' (Holloway cited in LenoxConyngham, 1998: 233), echoing Sennett's (2002: 75-6) account of the theatre-going public in France during the 18th century. The threshold of shame was not so well advanced that bodily functions could not be articulated publicly. At a trade union meeting in 1908, a member, objecting to the importation of foreign commodities, displayed a roll of toilet paper in his hand proclaiming it to be made in Norway (Keogh, 1982: 39). A teacher's manual (De Sales, 1909: 44) declares, 'Constipation. - This mortal foe of the teacher may be cured or prevented by taking soft food, such as porridge, soups, vegetables, and fruit.' There were at this time divergent class standards in terms of expectations of self-steering conduct. During the trial of a tailor for desertion of his wife and family in 1906, he declared that he had refused his wife her allowance as he had been 'on the cod', which the returning officer had to explain to the judge as 'out drinking', thus indicating distinct class symbolic resources. Similarly, Andrews, born in 1901 into a 'lower middle class [family] of the Catholic population' (1979: 13) and who became a prominent official in various public services, recalls the clear consumption practices according to class position. Dublin medical specialists and barristers, for example, 'had dinner in the evening, and dressed for it' (1979: 10); slightly below in the social scale - for example, publicans, butchers, and civil servants people 'had dinner in the middle of the day ... played rugby, cricket and tennis, but not golf or croquet' (p. 11). While there were certainly emulation processes between the various strata, this was more a matter of maintaining 'respectability' or attaining status than distinctive self-expression. Keogh (1982: 31-2) notes that craftsmen such as printers, drapers and bakers wore bowler hats to distinguish themselves from the labourers who wore cloth caps.

While a stronger sense of individuality developed in accordance with increasing and changing social interdependencies, this was not based on a courtly model of conduct diffused 
throughout the population. The antagonism between the national we-group and the former colonizing they-group (the British) developed a we-ideal inimical to displays of refinement and social superiority, though at the class level of social identification such feelings of superiority were often present and explicit prior to independence and no doubt continued in more muted form. Thus, the direction of social standards concerning more stable self-control and restraint developed somewhat contradictorily and unevenly, depending on one's position and function in the figuration. Even where individuality is implicitly addressed in terms of consumption practices in the earlier period, it tended to refer to a common social standard. For example, a newspaper advertisement at the turn of the century for a small town shop declares: 'You will get full value from me. I don't promise the world and all, but I do say if I cannot satisfy you in every particular, you must be mighty hard to please' (quoted in Gilligan, 2002: 240). Here, the potential customer is addressed implicitly as limited by the general expectations of the social standard of consumption, such that a desire to exceed them marks the individual as peculiar. The advertiser assumed that readers would wish to avoid being considered as 'hard to please'.

Although newspaper editorials at the beginning of the 20th century rarely used the concept of 'the consumer', it tended to connote the general public as users of a particular good or service rather than a sovereign individual. In particular, consumers were depicted as requiring protection from fraudulent producers or those willing to adulterate products. For example, The Irish Times (1904) editorial states:

It is simply appalling to note the fraud extensively perpetrated on consumers of alcoholic beverages. . . . horrible stuff is sold at very profitable prices. In the slums of Dublin concoctions are retailed under the name of whiskey which are only a degree less deleterious than the mixtures that would figure in the poison list . . . [It is wrong] to hoist upon the public as first-rate whiskey which is in reality a most unwholesome beverage. . . The Irish consumer has a right to have his interests safeguarded.

Another columnist laments the consumption of foreign goods (Hamilton, 1907):

Here, we, the consumers, are the sinners without even a gleam of grace. The amount of foreign-made goods . . . that comes in from England to Irish people is amazing . . . The most of that cheap foreign stuff is shoddy made by sweated labour . . . and our people are guilty of a grave moral wrong in purchasing such goods.

The conflation of the consumer and the public symbolizes the greater group (social) aspects of consumption at this time. Many consumption practices were not beyond the moral surveillance of others, they were not seen as primarily a matter for the individual positioned outside the expectations and compulsions of other people.

From the 1920s, parliamentarians were keen to impose constraints on consumption practices, justified in terms of the duty of patriotism. In the 1920 Bill for the Protection of Irish Industries ${ }^{1}$ the principle of state control was strongly endorsed: 'the protection of Irish Industries must take the form chiefly of discrimination by individual citizens in favour of Irish products'. Deputy Walsh, a trade unionist, contended that the 'Irish public were asleep as regards their duty to support Irish manufacture'. ${ }^{2}$ Ó Broin (n.d.: 7) confirms that his father 
ensured any boots bought would be Irish made. When sent to a shop to buy a non-Irish item, Ó Broin's mother told him 'not to tell [my father] where it came from' (Ó Broin n.d.: 8). So although there were strong social constraints to consume in a certain way, favouring the social group to which one belonged, these could be evaded in the absence of effective mutual observation. Such social constraints had not been effectively inculcated within the self to the extent that consumer choices seem natural and individually sovereign. The fear of being discovered by powerful others for social transgression of consumption norms was stronger than the fear of self-generated guilt and anxiety (though such 'internal' fears are socially induced through childhood). People consumed particular goods more by virtue of 'external' factors such as group membership or income constraints, rather than an 'inner' feeling of taste. The relative pacification of social relations, both in terms of physical violence and emotional outbursts, between class, religious and ethnic groups, under the social conditions of decreasing inequality brought on by increasing social interdependencies, encourages the belief that one's consumption choices are self- rather than socially derived and driven. In the relative absence of overt social conflict, people come under less explicit pressure not to betray affiliation by the display of 'they-group' goods and symbols. Bitterness toward former enemies can persist of course, but it tends to contradict new social pressures to temper animosities. Indeed, such suppression of felt hostility can exacerbate the sense that such feelings are emanating from within, rather than relating to clear social divisions. Andrews (1979: 307) recalls his impression of seeing a photograph of the President of the Irish Free State attending a function at Buckingham Palace shortly after the Civil War: 'His silver buckled shoes, silk stockings, velvet knee breeches, lace shirt and velvet jacket looked painfully ridiculous', as it demonstrated a measure of continued deference to the English Crown.

Though strong social constraints and hostilities existed, these went hand in hand with socially legitimated forms of leisure that also indicate a relative lack of psychic distance between people (depending on relative class position). Kearns (cited in Kennedy, 1998: 126) describes the key leisure events in Dublin tenements in the 1920s and 1930s, weddings and wakes, when beds were removed to the common social space of the landing to allow neighbours to drift in and out of the celebrations: 'Usually the festivities spilled out into the street for all to enjoy. A lively wedding could last from a few days to a full week.' There was little sense of privacy and less concern with punctuality and temporal calculability and predictably in the context of shorter and narrower chains of interdependencies for working-class people. Such occasional social licentiousness in leisure pursuits and consumption practices was even espoused by some parliamentarians; during a debate on alcohol taxes, Bourke, a rural politician born in 1873, quoted a songwriter's verse in praise of 'lashings of stout [beer] on the table', ${ }^{3}$ in order to assert the right of farmers and workers to cheap alcohol. The emphasis on social regulation of consumption included political concerns with the prices of products, particularly 'necessaries' such as food and clothing. This often led to public expressions of contempt for those that sought to advance their own interests to the detriment of the common good, i.e. 'profiteering' retailers and shopkeepers. However, retailers were often in a strong power relation with customers because of the advancing of products on credit, which produced inhibitions against informing to state authorities. In terms of the implementation of price control by the state, Morrisey envisaged the consumer as a major impediment:

It seems to me that the greatest difficulty the Commission to control prices will have to contend with will be the apathy of the public - the apathy of the consumers - and that it will be found even where there was overcharging - perhaps gross overcharging - while the consumers will grumble and grouse, they will be very slow to come 
forward to give evidence. That was the experience of the Food Prices Tribunal which was set up by the late Government. ${ }^{4}$

Here again the public and consumers are conflated, emphasizing a more common subject of consumption (though class dimensions had persisted). However, not all deputies exhibited such a negative view of retailers and distributors. McGilligan stated that price fixing would be a negative departure for the state as it implied excessive intervention in the affairs of business. Responding to the charges of price differentiation among retailers for the same type of goods by other deputies, he stated that prices differ because people are 'getting something else than the article that they buy. They are getting service of a type that they would probably not get in the other shops. ${ }^{5}$ This indicates that he perceived a degree of heterogeneity of needs and preferences among consumers that warranted diverse pricing levels. He implied that people knowingly chose particular shops based on some preference criteria including price and service. Whether this is absolutely true or not, the argument was still discursively available to him, and his disagreement with other politicians reflects a different class habitus, and consequently a divergent conception of the consuming subject. According to Daly (1992: 14), McGilligan, a barrister, had taken economics as a student at University College Dublin, and would become professor of law there in 1934. He also read widely in economics and international finance after leaving government (McCullough, 1998: 49).

Up to the 1940s, there was a dominant ethos of self-reliance: people were expected to provide for their own needs through work or farming. Consumption was considered a vital mechanism in the compulsion to work. Without the threat of loss of access to basic commodities, politicians feared that some might not work at all and would thereby place extra demands on other more productive citizens. According to Eamonn Coogan in 1947: "Our attitude to these seekers of doles should be: "You will get nothing for nothing and damn little for a half penny.", Again this indicates the cultural assumption that people should be compelled to work by others (an active social compulsion to individual action) without which their own self-steering mechanisms would be too weak. Though Coogan accepted the duty of the government to ensure employment opportunities: where 'employment can be found, these people, provided they are fit, should be compelled to work'. So the ethic of selfreliance went hand in hand with a felt need for strong social regulation. Coogan even defines these 'work-shy gentlemen' as 'anti-social', meaning they have failed in their duty to take care of themselves and their families, and to the broader society of which they are a part.

In the same debate, Patrick Giles, a farmer, opined that the nation had become 'a spoiled child' with people 'running to the shop and buying everything they need, instead of producing it'. This quote demonstrates not only a valorization of a more autarkic existence, but also an anxiety regarding the quickening pace of social differentiation and integration. The lengthening chains of social interdependency enable, and are enabled by, expanding commodity exchange networks, which produce feelings of resentment and nostalgia for those socialized into taking care of their own needs. The ethic of self-reliance should not be confused with the development of clear self-steering mechanisms in the field of consumption. Self-reliance is not the same thing as self-constraint (Mennell, 2004: 133); the latter refers to the need and capacity to adjust and control one's conduct, while the former valorizes the capacity to provide for one's own needs without depending on others. The public expression of this ethic is in fact a sign of the increasing significance of goods and services in social relations. This change is itself an outcome and driver of increasing social interdependencies; as people become more embedded in relations of exchange, in terms of processes of production, shopping and consumption, they must attune their conduct to 
facilitate the navigation of more complex social networks. This greater complexity combined with more even power balances between classes diminishes the propensity to subject people to overt, explicit surveillance.

New symbols or expanded meanings of established concepts, such as 'the consumer', emerge to reflect and facilitate the changing social landscape. But, pace Foucauldian approaches, these symbolic changes are not the sole result of discursive mechanisms or contradictions; rather they are part of a new means of orientation and communication between actually or potentially interdependent people in developing figurations. There are, of course, contradictions, as those socialized into less extensive or more polarized figurations must contend with new social realities; their habitus feels at odds with the emerging standards and expectations. It is these disjunctures that give rise to nostalgia for past cultures of consumption. By the 1960s, the emphasis on the social generation of needs and social regulation of consumption practices was receding, while the concern for providing the conditions for consumer self-expression and self-determination of wants (and their fulfilment) advanced. This, echoing Elias (1991a), represents a shift in the balance between we- and I-identity towards the latter, bearing in mind this is an unstable balance rather than a linear stage-like progression. People did not rapidly shift their mode of orientation and action from others to themselves, but there was a developing expectation among politicians that people be more self-steering in their conduct. In 1960, McGuire lamented the continuing mentality that preferred social to self-control: 'Many of our citizens are not only resigned to the State guiding and controlling their destinies and activities but they acquiesce in that state of affairs; not only that, but many demand more and more State benevolence and control. ${ }^{7}$ Others, such as Patrick Donegan, doubted the state capacity to regulate television viewing, believing this to be an outcome of personal preference: 'Our people - patriotic and nationally-minded as they may be - will sit down at night and look and listen to the programme they prefer. ${ }^{8}$

In 1962, politicians quoted reports of the Committee on Industrial Organization, established by the government, which had expressed the view that patriotism would not save commercial enterprises in Ireland from the effects of freer trade following accession to the European Economic Community (EEC). ${ }^{9}$ The decline in patriotic consumption indicates a growing emphasis on a self-steered mode of need satisfaction. One of the subsequent committee (Committee on Industrial Organisation, 1964) reports on the furniture industry warned of inadequate product standards, lack of focus on design and the fact that 'no systematic investigation of the buying public's needs or desires has ever been made' (1964: 73, my emphasis). The expansion of needs to desires demonstrates a relative autonomy of individual wants from socially sanctioned requirements. Though specifying 'the buying public', here it is clear the committee envisaged a more differentiated subject of consumption as they stressed the need for 'narrower specialisation' (1964: 81) of production.

By the 1970s, the resentment and nostalgia of some politicians for a more socially controlled consumer subjectivity had largely disappeared. In 1974, Justin Keating welcomed proposed consumer protection legislation on the grounds that it would be in the interests of 'satisfying the needs of a more sophisticated public'. ${ }^{10}$ It would also benefit the retailing sector whose aim 'is to satisfy to the highest level the wishes and needs of the customers' (my emphasis). Similar to the Committee on Industrial Organisation's expansion of manufacturer responsibility to address desires as well as needs in the 1960s, Keating stressed the importance of consumer wishes, again supporting the conclusion that the consumer had become more individualized. Consumer preoccupations had become more relatively 
autonomous from social compulsion, corresponding to Bauman's (2001; Rojek, 2004) contention that needs have expanded to incorporate wishes. For many consumers, according to Paddy O'Toole, 'times have changed and ... consumers are now faced with a bewildering amount of products'. Increasingly, consumers had no choice but to choose. The occupational or hereditary basis of social status was also assumed to be in decline, as O'Toole thought many consumers were being persuaded that 'social status is measured by the frequency with which people can purchase and replace items'. Rising social pressure on individuals in their conduct as self-steering consumers is also evident in O'Toole's comment that 'when a person makes what turns out to be a foolish purchase we castigate him for being careless ... Sometimes these people are referred to as careless consumers'.

The growing focus on the need to know the consumer, to understand and satisfy his or her needs, desires and wishes reflects a growing psychological distance between producer and consumer, between one individual and another. In a social world of a relatively undifferentiated, common subject of consumption the task of knowing another appears simple - one's needs reflect a common, inherited social fund of knowledge. It is only in the world of subjective differentiation that the psychic distance grows and the difficulty and reticence in understanding another emerges. The individualized consumer is also increasingly faced with the problem of choosing what he or she really wants; the social compass of choice has become more opaque.

The increasing individualization of the period can also be seen over the course of a single lifetime. The memoirs of a retired schoolteacher demonstrate the contempt of an older generation for modern conveniences; he recalls how girls used to wash their hair in rainwater without 'any medicated shampoos for greasy or dry hair or any of that nonsense' (O'Farrell, 1986: 25). Such 'nonsense' of course indicates not only product differentiation but also an assumption of the subjective, special needs of different types of person. The closer psychic distance between people in these less complex societies was also associated with less impermeable barriers between people and things - O'Farrell (1986: 28) describes how housekeepers of old poked and prodded at a side of bacon until the poor grocer was strangled turning it around for inspection . . . Today, the daughters of these women drive up their wire prams full of wrapped nothings and pay on the nail for everything. The whole operation has become impersonal.

\section{FIGURATIONAL SHIFTS}

Over the course of the 20th century, the network of mutual dependencies affecting most people in Ireland became more extensive and all-pervasive. These interdependent links extended far beyond the nation state itself, to include figurations in Europe and America. Of course, these interdependencies existed for some people in previous centuries, but more and more people of diverse class positions had to succumb to a wider variety of social pressures to control themselves and attune their conduct according to specific power relations. However, these changes did not proceed evenly, though there was a specific order or structure to the changes.

One major impetus to greater interdependencies within Ireland was occasioned by increasing competition between Irish farmers and those from other states, such as Denmark, for consumers in Britain (Lee, 1989a, 1989b). As Britain became more industrialized over the 19th century, many people in Ireland specialized in the cultivation of specific crops or the breeding of specific animals; a greater functional specialization and social differentiation occurred bringing more small and subsistence farmers into a developing network (figuration) 
of exchange based on different phases in the production and distribution of food. This in turn led to the expansion of nodes of administration and commercial exchange (towns and cities), which required more extensive transportation networks and more effective control of security through state apparatus to ensure safe carriage of goods. The growing interdependency between Irish producers and English consumers (and of course Irish consumers) led to the compelling trend of larger and more mechanized farms, thereby displacing much of the rural population. Both migration to towns, to take up new social functions of administration and distribution, and emigration to America, in particular, increased. According to the Census of Population (1926 to 1981, Central Statistics Office Ireland, n.d.) 51 percent of the labour force were engaged in agricultural occupations in 1926 , which declined to 16 percent by 1981 . The main period of decline was after 1951, when 40 percent of the labour force was still engaged in agriculture.

I emphasize the agricultural labour force here because life on farms is relatively autarkic compared to the more socially complex figurations of industrial and post-industrial cities. Farmers were of course interdependent with each other, and with landowners and eventual consumers, but the everyday existence of farmers and agricultural labourers were subject to less pervasive and varied social pressures than those living in urban areas engaged in professional, manufacturing and service occupations. As Elias (2000: 380) notes, the effect of specific figurations on individuals depends upon their role and position within them; someone on the periphery may not perceive the effect of other's behaviour on their own life chances, while those more centrally located are compelled to exercise a more 'steady control of conduct'. Even the figurations comprising farmers became more complex and multilayered. The distribution of farm sizes changed such that 16 percent of farmers owned land of more than 100 acres in 1981 compared to only 8 percent in 1926. This reflects the upward movement of 'viable' farms in terms of size; the Land Commission had designated 20 acres as the minimum for viability in the 1920s, but increased this to 45 by the 1960s (Sammon cited in Fahey, 2002: 57). The pressure for reliable and consistent supplies of farm produce encouraged the development of agricultural cooperatives, which underwent a process of amalgamation throughout the 20th century, enmeshing farmers and administrative specialists in such organizations into tighter and more extensive webs of interdependence.

In the Irish nation state as a whole, the proportion of people who lived in towns of more than 1500 people rose from 32 percent to 52 percent between 1900 and 1971 (Vaughan and Fitzpatrick, 1978). This urbanization process represented an advance in the density and length of social interdependencies between Irish people, and between the Irish and other nationalities. In towns and cities in Ireland the growing urban population created pressure in the search for social functions, and occasional outbreaks of violence and conflict between employing and working classes. The power relation became less unequal through the growth of trade unions, and in a spiralling process, the creation of employer organizations. This mutual constitutive process created multi-tiered social institutions with new mediating social functionaries to negotiate compromises between opposing classes, thereby pacifying relationships to some extent. People in urban contexts become subject to greater social control and also greater socially expected self-control. The greater interdependency between urban social classes led to a reduction in animosity and advancing thresholds of concern for the poor and disadvantaged. This in turn expanded the role and responsibilities of politicians who sought to maintain industrial peace as they were also dependent on all adults for votes. The growth of the welfare state (Cousins, 2003) also pressurized politicians to extend taxation and generate employment. 
Continuing emigration became a growing source of shame for a new nation state (securing a measure of independence from Britain in 1922), as America increased restrictions on immigration, and England (the former colonizing group) became the main destination for Irish emigrants. Over 12,000 people emigrated to the USA in 1920 compared to only 469 to England (Vaughan and Fitzpatrick, 1978: 265-6). During the 1950s, an average of 40,000 people per year emigrated, the vast majority going to England. According to Rottman and O'Connell (1982: 69), of those born between 1936 and 1941 only 59 percent remained in Ireland by 1961. This in turn led politicians to forsake protectionist economic policies; foreign investment was increasingly sought, which again expanded social inter dependencies and further enmeshed Irish people within a more global system of production, exchange and consumption.

Ireland continued in a highly asymmetrical social figuration with Britain up to the 1960s. But between 1938 and 1985, the dependency on the UK as a destination for exports declined from 93 to 33 percent (Kennedy et al., 1988: 183). The social figuration of Ireland had become more interdependent with, and more integrated into, a diversity of nation states. This occurred not only in the 'economic' sphere, but also the political and cultural as Ireland acceded to the EEC in 1973. The policy of attracting foreign industrialists, which accelerated after 1958, advanced Ireland's global integration. Whereas only 16 percent of manufacturing output was exported in 1951, this increased to 64 percent by 1988 (O'Malley, 1992: 33-4). By that time, foreign firms accounted for 44 percent of manufacturing employment and 75 percent of manufacturing exports (O'Malley, 1992: 39). This does not refer to simply economic processes, as foreign capital was induced through state initiatives and developing knowledge of the needs of industrialists concerning choice of location.

The relatively rapid change in available social functions and their differentiation and integration meant, of course, that people increasingly depended on the services and products of others. It also meant people had to quickly adopt their conduct to unfamiliar social networks, relying on pre-existing symbolic and emotional repertoires that were inadequate. The search for new models of conduct, and the need to observe oneself in the context of new social relations, was experienced as a source of tension and anxiety. The wider, more global sources of pressure on people meant they had to suppress former feelings of antagonism with opposing groups, whether Irish employers or foreign industrialists. Growing equalization, within the context of increasing social interdependencies, discouraged people from strongly prescribing courses of action for others, and the lack of conduct models meant people increasingly felt the need to navigate the social terrain as individuals. Growing circumspection and calculation in some social relations encouraged a feeling of psychic distance, though this might be compensated with growing intimacy in family and friendship networks. The development of the ideal of individuality - within limits, as social expectations did not disappear - was the unplanned but ordered outcome of figurational shifts and power realignments. The increasingly individualized consumer subjectivity is a version of this more general trend towards individualization.

\section{CONCLUSION}

Consumer subjectivity cannot be separated from the broad and complex intertwining of multiple social processes that together constitute the social figuration of which each 'consumer' is a part. Thus, changes in the symbolic and emotional meaning of the 'consumer' has to be considered as a social process, understandable in terms of the shifting social interdependencies bonding people together, either in cooperative, competitive, hostile or supportive ways. Pace Foucauldian studies explaining consumer subjectivity through the 
mobilization of psychological discursive practices (Graham, 1997; Miller and Rose, 1997; Reith, 2004; Rose, 1990), the apparent discontinuity in discourse and techniques neglects the social continuity in terms of contingent connections between various stages of development in figurations. Also, changes in consumption practices and subjectivity are not simply the result of obvious agencies of inscription (such as consumer education programmes or marketing research organizations); theses attempts at knowing and persuading consumers are themselves based on a figurational shift that produces feelings of individuality and uniqueness. Such practices, though possibly influential, must be considered as part of the immanent social dynamic producing stronger feelings of individualization. This is still only a relative movement. Other forms of social identification do not disappear; they are supplemented by a stronger I-identity, which can feel in conflict with weidentities. Commercial organizations certainly seek to understand existing and potential consumers, but this is because of intensified social interdependence in tandem with growing social differentiation. The growing social pressures towards more even self-control have produced the feeling that other individuals are psychologically distant and separate, and new social functions and occupations of marketing specialists emerge to bridge the gap.

There is a way of synthesizing to some extent the Eliasian and more dominant Foucauldian approaches, echoing Binkley's (2007) attempt to connect governmentality and lifestyle studies. We can conceive of the development of consumer subjectivity in terms of different phases or moments of a figurational dynamic. The intentional practices and strategies of branding managers, market researchers and magazine editors occur at particular points when the potential consumer already feels receptive to such discursive practices. The various discursive appeals and injunctions to consume according to one's individuality and uniqueness find resonance with the audience once the trajectory of figurational dynamics allow such appeals to be heard and enacted. We must understand advertiser plans and intentions within the antecedent, broader social processes and networks that are unplanned and unintentional.

\section{Acknowledgements}

The author would like to thank Don Slater for his supervision of the research process on which this article is based. He also acknowledges the support of the Irish Research Council for the Humanities and Social Sciences through a Senior Research Scholarship award during 2004-05. He is grateful to the anonymous reviewers for helpful comments.

\section{Notes}

1. Dáil Debates (DD), volume F, column 229-31, 17 September 1920. All material cited comes from the Parliamentary Debates archive (n.d.).

2. $D D$, volume F, column 230, 17 September 1920.

3. $D D$, volume 63, column 317-8, 25 June 1936.

4. Daniel Morrisey, DD, volume 44, column 131, 19 October 1932.

5. $D D$, volume 44, column 2060, 17 November 1932.

6. $D D$, volume 105, column 495, 28 March 1947; see also Vivian de Valera and

Patrick Giles, column 502-8.

7. Seanad Debates (SD), volume 52, column 123, 21 January 1960.

8. SD, volume 52, column 152, 21 January 1960.

9. Norton, $D D$, volume 194, column 1818, 11 April 1962; McGilligan, DD, volume 195, column 408, 8 May 1962; Corish, DD, volume 195, column 98-9, 
2 May 1962.

10. $D D$, volume 272, column 94, 24 April 1974.

11. DD, volume 309, column 1118-20, 16 November 1978.

\section{References}

Andrews, C.S. (1979) Dublin Made Me: An Autobiography. Dublin and Cork: The Mercier Press.

Ashley, S. (2001) 'The Politics of Race in 1890s Ireland: An Ethnography of the Aran Islands', Patterns of Prejudice 35(2): 5-18.

Bauman, Z. (2001) 'Consuming Life', Journal of Consumer Culture 1(1): 9-29.

Binkley, S. (2006) 'The Perilous Freedoms of Consumption: Toward a Theory of the

Conduct of Consumer Conduct', Journal for Cultural Research 10(4): 343-62.

Binkley, S. (2007) 'Governmentality and Lifestyle Studies', Sociology Compass 1(1): $1-16$.

Brewer, J. and Trentmann, F. (2006) 'Introduction: Space, Time and Value in Consuming Cultures', in J. Brewer and F. Trentmann (eds) Consuming Cultures, Global Perspectives: Historical Trajectories, Transnational Exchanges, pp. 1-17. Oxford and New York: Berg.

Central Statistics Office Ireland (n.d.) Census of Population Reports. Dublin: Stationery

Office.

Clarke (2007) 'Unsettled Connections: Citizens, Consumers and the Reform of Public Services', Journal of Consumer Culture 7(2): 159-78.

Cohen, L. (1998) 'The New Deal and the Making of Citizen Consumers', in S. Strasser, C. Mcgovern and M. Judt (eds) Getting and Spending: European and American Consumer Societies in the Twentieth Century, pp. 111-25. Washington, DC and Cambridge: Cambridge University Press.

Cohen, L. (2001) 'Citizens and Consumers in the United States in the Century of Mass Consumption', in M. Daunton and M. Hilton (eds) The Politics of Consumption: Material Culture and Citizenship in Europe and America, pp. 203-21. Oxford and New York: Berg.

Committee on Industrial Organisation (1964) Report on Survey of the Wood and Metal Furniture Industry (Pr. 7484). Dublin: The Stationery Office.

Cousins, M. (2003) The Birth of Social Welfare in Ireland, 1922-1952. Dublin: Four Courts Press.

Cross, G. (1993) Time and Money: The Making of Consumer Culture. London:

Routledge.

Curtis, L.P. (1997) Apes and Angels: The Irishman in Victorian Caricature. Washington, DC and London: Smithsonian Institution Press.

Daly, M.E. (1992) Industrial Development and Irish National Identity, 1922-1939.

Dublin: Gill and Macmillan.

Delhaye, C. (2006) 'The Development of Consumption Culture and the Individualization of Female Identity: Fashion Discourse in the Netherlands 1880-1920', Journal of Consumer Culture 6(1): 87-115.

De Sales, B. (1909) The Teacher's Companion. Dublin and Belfast: The Educational Company of Ireland.

Dolan, P. (2005) 'The Development of Consumer Culture, Subjectivity and National Identity in Ireland, 1900-1980', unpublished $\mathrm{PhD}$ thesis, University of London (Goldsmiths College).

Elias, N. (1983) The Court Society. Oxford: Blackwell. 
Elias, N. (1987) Involvement and Detachment. Oxford: Blackwell.

Elias, N. (1991a) The Society of Individuals. Oxford: Blackwell.

Elias, N. (1991b) The Symbol Theory. London: Sage.

Elias, N. (2000) The Civilizing Process: Sociogenetic and Psychogenetic Investigations (revised edition). Oxford: Blackwell.

Fahey, T. (2002) 'The Family Economy in the Development of Welfare Regimes:

A Case Study', European Sociological Review 18(1): 51-64.

Gilligan, J. (2002) 'Murray's of Dunshaughlin', in D.A. Cronin, J. Gilligan and

K. Holton (eds) Irish Fairs and Markets: Studies in Local History, pp. 224-47. Dublin:

Four Courts Press.

Graham, L. (1997) 'Beyond Manipulation: Lillian Gilbreth's Industrial Psychology

and the Governmentality of Women Consumers', Sociological Quarterly 38(4):

539-65.

Hackley, C. (2002) 'The Panoptic Role of Advertising Agencies in the Production of

Consumer Culture', Consumption, Markets and Culture 5(3): 211-29.

Hamilton, J. (1907) 'Curse of Credit: Effect on Irish Trade', Irish Independent, 7

March, p. 4.

Hilton, M. (2001) 'Consumer Politics in Post-War Britain', in M. Daunton and

M. Hilton (eds) The Politics of Consumption: Material Culture and Citizenship in

Europe and America, pp. 241-59. Oxford and New York: Berg.

Irish Times (1904) Editorial, The Irish Times, 8 April, p. 4.

Jantzen, C., Østergaard, P. and Vieira, C.M.S. (2006) 'Becoming a "Woman to the

Backbone": Lingerie Consumption and the Experience of Feminine Identity',

Journal of Consumer Culture 6(2): 177-202.

Kee, R. (2000) The Green Flag: A History of Irish Nationalism. London: Penguin.

Kennedy, F. (1998) 'Family Life', in K.A. Kennedy (ed.) From Famine to Feast:

Economic and Social Change in Ireland, 1847-1997, pp. 123-33. Dublin: Institute of Public Administration.

Kennedy, K.A., Giblin, T. and McHugh, D. (1988) The Economic Development of Ireland in the Twentieth Century. London: Routledge.

Keogh, D. (1982) The Rise of the Irish Working Class: The Dublin Trade Union Movement and Labour Leadership, 1890-1914. Belfast: Appletree Press.

Keogh, D. (1994) Twentieth-Century Ireland: Nation and State. Dublin: Gill and Macmillan.

Lee, J. (1989a) Ireland 1912-1985: Politics and Society. Cambridge: Cambridge University Press.

Lee, J. (1989b) The Modernisation of Irish Society: 1848-1918. Dublin: Gill and Macmillan.

Lenox-Conyngham, M. (ed.) (1998) Diaries of Ireland: An Anthology, 1590-1987.

Dublin: The Lilliput Press.

McCullough, D. (1998) A Makeshift Majority: The First Inter-Party Government, 1948-51. Dublin: Institute of Public Administration.

Mennell, S. (2004) 'The American Civilizing Process', in E. Dunning and S. Mennell (eds) Norbert Elias, Vol. 2, pp. 119-36. London: Sage.

Miller, D. (2001) 'The Poverty of Morality', Journal of Consumer Culture 1(2):

225-43.

Miller, P. and Rose, N. (1997) 'Mobilizing the Consumer', Theory, Culture \& Society 14(1): 1-36.

Ó Broin, L. (n.d.) Just Like Yesterday. Dublin: Gill and Macmillan.

O'Malley, E. (1992) 'Problems of Industrialisation in Ireland', in J.H. Goldthorpe and 
C.T. Whelan (eds) The Development of Industrial Society in Ireland, pp. 31-52.

Oxford: Oxford University Press.

O'Farrell, P. (1986) 'Tell Me, Sean O'Farrell': The Story of an Irish Schoolmaster. Cork and Dublin: Mercier Press.

Parliamentary Debates (n.d.) Archive, Office of the Houses of the Oireachtas, Dublin.

URL (accessed 10 January 2007) http://historical-debates.oireachtas.ie/

Reith, G. (2004) 'Consumption and Its Discontents: Addiction, Identity and the Problems of Freedom', British Journal of Sociology 55(2): 283-300.

Rojek, C. (2004) 'The Consumerist Syndrome in Contemporary Society: An

Interview with Zygmunt Bauman', Journal of Consumer Culture 4(3): 291-312.

Rose, N. (1990) Governing the Soul: The Shaping of the Private Self. London:

Routledge.

Rose, N. (1996a) 'Authority and the Genealogy of Subjectivity', in P. Heelas, S. Lash

and P. Morris (eds) Detraditionalization: Critical Reflections on Authority and Identity, pp. 294-327. Oxford: Blackwell.

Rose, N. (1996b) 'Identity, Genealogy, History', in S. Hall and P. Du Gay (eds)

Questions of Cultural Identity, pp. 128-50. London: Sage.

Rottman, D.B. and O'Connell, P.J. (1982) 'The Changing Social Structure', in

F. Litton (ed.) Unequal Achievement: The Irish Experience, 1957-82, pp. 63-88.

Dublin: Institute of Public Administration.

Schild, V. (2007) 'Empowering "Consumer-Citizens" or Governing Poor Female

Subjects? The Institutionalization of "Self-Development" in the Chilean Social

Policy Field', Journal of Consumer Culture 7(2): 179-203.

Sennett, R. (2002) The Fall of Public Man. London: Penguin.

Slater, D. (1997) Consumer Culture and Modernity. Cambridge: Polity Press.

Trentmann, F. (2006a) 'Knowing Consumers - Histories, Identities, Practices: An

Introduction', in F. Trentmann (ed.) The Making of the Consumer: Knowledge, Power

and Identity in the Modern World, pp. 1-27. Oxford and New York: Berg

Publishers.

Trentmann, F. (2006b) 'The Modern Genealogy of the Consumer: Meanings,

Identities and Political Synapses', in J. Brewer and F. Trentmann (eds) Consuming

Cultures, Global Perspectives: Historical Trajectories, Transnational Exchanges,

pp. 19-69. Oxford and New York: Berg Publishers.

Trentmann, F. (2007) 'Introduction: Citizenship and Consumption', Journal of

Consumer Culture 7(2): 147-58.

Vaughan, W.E. and Fitzpatrick, A.J. (eds) (1978) Irish Historical Statistics: Population, 1821-1971. Dublin: Royal Irish Academy.

Wouters, C. (2004) Sex and Manners: Female Emancipation in the West, 1890-2000.

London: Sage. 